\title{
2-4 個人生活における未来テレビの役割
}

\author{
正会員 柳 町 昭 夫 $^{\dagger}$
}

\section{1. ま え がき}

マルチメディアが進展し, 個人の生活レベルにまで 浸透するようになる段階では，マルチメディア情報通 信のインフラが整備され，少なくともビジネスの場に おいては, マルチメディアによるビジネス習慣が確立 し，また，公共的サービスにおいてもマルチメディア によるサービスの高度化が進んでいると想定するのが 妥当であろう。そのような社会環境に身におく個人が 自身の生活において，今日のテレビからマルチメディ ア化の進化をとげた「未来テレビ」にどのように接し， 何を期待するようになるであろうか？

\section{2. 現行テレビの視聴行動から}

テレビ放送が開始された当初はプロレス中継を街頭 テレビの前や電気店の店先に並んで見, やがてテレビ が普及すると, 各家庭の茶の間にテレビが据えられ， ニュースやドラマ, オリンピック中継, アポロ宇宙中 継などを家族団らんの中で見て楽しみ，それが人々の 共通の話題ともなって生活の中に溶け込んでいた。今 日では, テレビセットの低価格化，リモコンの登場， VTRの兼及などによって, テレビはより個人的に見 られる傾向にあり, テレビの基本的な役割は変わらな いと考えられるが，テレビ視聴行動は変化してきてい る.

テレビが生活場面で主役的な存在でなくなっだ)と はいえ，個人にとって役立つメディアとしてテレビが 意識されていることは，ここ 10 年来変わらない2). テレビで何を見ているかについては，ニュース，天気 予報, ドラマ, スポーツ, クイズ，ゲーム，歌・音楽 番組などがよく見られ，一般教養番組，政治・経済・ 社会番組, バラエティ, ワイドショー, 映画, 演芸も の, 生活実用, アニメマンガ, 講座番組の順でつづい ている.最近の調査では, 1 日のテレビ視聴時間量 (週平均, 94 年 6 月調査 $\left.{ }^{3}\right)$ は 3 時間 27 分である。こ

$\dagger$ NHK 放送技術研究所

"2-4 Future Television in Personal Life" by Akio Yanagimachi (NHK Science and Technical Research Laboratories, Tokyo)
のように，多くの基本的情報の入手手段であり，日常 的な誤楽, 教養のメディアでもある今日のテレビは個 人の生活に深くかかわっている.

約 20 年後のマルチメディア時代に中心的世代とな る, 団塊ジュニアのメディア感覚 ${ }^{4)}$ から, 今日のテレ ビとのつきあい方, 楽しみ方を見てみると, コマーシ ヤルになるとチャンネルを切り替え, また, チャンネ ルを切り替えながら同時に 2 つの番組を見るザッピン グ視聴はあたりまえという姿が見えてくる．限られた 生活時間の中で, リモコンによるチャンネル切り替え を多用したり,またVTRの早送りなどにより, 番組 の面白いところだけを見たり, より多量な情報収集を することでテレビの満足度を高めていることが推察で きる，団塊ジュニアは，本， CD，ビデオ，テレビゲ 一ムやパソコンなど豊かなメディア環境に身をおきな がらも, テレビを共通の話題の情報源や，世界のいろ いろな出来事がよくわかる情報メディアとして必要不 可欠なものと感じている．また，ビデオやテレビゲー ムを放送のチャンネルの選択性の延長として受け止め ているようでもある。つまり，テレビに映るものはテ レビだ, ということであろう.

前出の調査 ${ }^{2)}$ で，未来のテレビへの期待を尋ねた中 で，見たいときに見たいものが見られる，あるいは知 りたい情報を呼び出せる, 使い勝手のきくテレビや, 立体的に映像を見ることができるテレビへの期待が膨 らんでいることが示された。

\section{3. 未来テレビの利用イメージ}

\section{(「Future Television 201X」のストーリーから)}

放送がマルチメディアとして開花すると考えられる 今から 15〜20 年後のテレビのひとつのビジョンとし て, ハイビジョンイメージソフト「Future Television 201X」を制作した。このイメージソフトは，技術的可 能性を基本的なべースとしながら，「このようなメデ イア, サービス, 番組があったらよい」というユーザ 側の視点からコンセプト ${ }^{5)}$ を作り，夢もまじえて描い たものである．この「Future Television 201X」のス トーリーを追いながら，個人生活における未来テレビ の役割を考えてみる。 
一ストーリーの主人公はある少女あやか．199 X 年のある日, テレビを見ながらひとりで留守番をし ていた彼女は，寂しさと退屈から，母親からもらっ て大切にしていたクマのぬいぐるみにあたりちらし てしまう。ぬいぐるみをテレビに投げつけた拍子 に，ぬいぐるみとともに画面の中の未来の世界へ夕 イムスリップ.たどりついた世界は, 20 年後の 201 $\mathrm{X}$ 年. 見失ったクマをさがしながら，未来の自分 やその家族に出会い，そこで使われている未来のテ レビを体験する。

あやかが最初に見たのが, リビングで未来テレビ を操作するもう一人のあやか（じつは未来の自分）. 画面には，「エージェント」と呼ばれる CG キャラク 夕が登場して未来のあやかと対話する（口絵写真 1).

\section{・ 未来テレビ（総合家庭端末）}

マルチメディア時代においても生活に必要な基本的 情報をテレビから得ることに変わりはないであろう． しかし，ユーザは，未来テレビを放送として利用する だけでなく, 電子化された新聞, 電子図書館など, 通 信型の映像サービスや自分のアルバムなどを記録して いるホームデータベースの端末としても利用するよう になろう。

未来テレビは大画面の高精細壁掛けディスプレイが 中心になり, リビングにはこの総合家庭端末としての 未来テレビが中心に置かれるであろう．ユーザの立場 から考えると, いろいろな端末が家庭の中にあること はスペースも取られ, 操作も複雑化するので, なるべ く機能を統合化したものが求められるのではないだろ うか. もちろん, 未来テレビも個人化への対応が必須 であり, 各種の機能統合のニーズに応える機種が商品 化され, 個人個人の利用環境にマッチしたものが得ら れよう。

・情報アクセスの「オートマ」機能=エージェント

多メディア, 多チャンネル, 多情報, 多サービスの 環境下で使われる未来テレビセットは, 情報アクセス の「オートマ」機能を果たすエージェント付のものが 売れ筋になる.エージェントはユーザの代わりにメデ イアへのアクセスや好みのソフトの選択などを代行し てくれる.エージェントとの対話は声で行うなど, ひ とにとってごく自然なヒューマンインタフェースを備 えたものになる.

未来テレビのメニュー画面はカスタム化され，ユー ザが常に見たい情報（例えば天気など）とともに，関 心のある番組ジャンルのインデックスが番組の概要が つかめる形で表示されるであろう.

\section{•「番組冷蔵庫」}

エージェントが管理を任されていることのひとつが 末来テレビの特徵的な機能である「番組冷蔵庫」. 端末 内の大容量メモリーを「冷蔵庫」のように使い, 番組 をストックする．ユーザは必要なときにいつでも希望 の番組を視聴できる. 番組のダウンロードは, 放送局 から送られる番組案内情報を使ってインテリジェント に行う。エージェントは, あたかも冷蔵庫が食品の鮮 度を保つように番組や情報の鮮度を保つ働きをし, 常 にメモリーがユーザにとって有用な最新の情報で満た されているように気配りをする。

\section{・ ハイライトシーン/データが呼び出せる}

一未来のあやかはサッカーの生中継を途中から見 始める. 誰が得点したのか気になり, ハイライトシ ーンやデー夕を呼び出す (口絵写真 2). また, いろ いろなカメラアングルを自分で選んで視聴する.

末来テレビのスポーツ中継ではハイライトがいつで も呼び出せる．また，サッカーのようなスポーツ中継 では, フィールド全体を見渡せる超広角高精細カメラ の映像も放送される。ちょうど競技場の一番良い座席 から見ているようになる。この映像から自分でズーム アップしたり, いろいろな演出のカメラアングルを選 択したりする。

競技を観戦する一方, 選手やチームのデータを必要 により呼び出すことができる.これは, 放送局が, 受 信端末側に備えるハイパーメディア型データベースの ための更新データ(動画, 音声を含む)として, 通常の 映像, 音声のほかに, 詳細データを放送するので可能 になる。

\section{- ハイパーニュース}

この形はスポーツ中継だけではなく, ニュースにも 適用される。すなわち, 通常の編集のニュースのほか に, より素材に近い詳細情報(参照情報)をハイパーメ ディア形式で放送する，ユーザは，ニュースの内容を 個人の興味やペースにしたがって「読む」ことができ る、ユーザにとっては, 情報を受動的に眺めるだけで なく，興味のあるあるいは自分が必要とする場合には 情報を積極的に読みとっていくような視聴行動が可能 になる。

マルチメディア時代には, 限られた生活時間の中で より効率的に情報を取得し, 利用しようとする傾向は ますます強まっていくだろう。これに応えて, 未来テ レビの放送局は, 個人の興味・必要に応じた仕方で情 報を提供する。

\section{- リアルタイム CG 教育番組の実験}

一あやかは, 未来の自分の子供レイの部屋に行 
き,レイが未来のテレビで学校の宿題をするのを見 る、レイが勉強机の上の薄い平面ディスプレイに軽 くタッチするとアクセスチャンネルのインデックス 画面が現れる（口絵写真 3)，その中からインタラク ティブ教育チャンネルを選び, 学校の宿題をはじめ る. 教科書には, 先生が動画で現れ話しかけてく る、レイは, 放送で送られてきた CG モデルを使っ て宇宙でものを投げたらどうなるかを自分で実験し

\section{てみる（口絵写真 4 ）。}

未来テレビの教育番組などでは, 映像内容に関連し たオブジェクト(物体あるいは説明用の模型)を, 受信 側で CG 再現することが考えられる。そのためには， 3 次元モデリングデータを映像とともに放送する。例 えば, 物理現象のメカニズムを理解する場合に, ユー ザは映像で展開される説明と対応させて, 受信端末の 上で送られた CG 模型を使い, 自由に実験をしてみる ことができる。また，オブジェクトを保存しておけば 「復習」することもできる.

\section{・ 放送局ヘオンデマンドアクセス/アップロード}

ーレイは見覚えのないぬいぐるみのクマを見つけ る.クマのしっぽがとれているのを見, 自分の端末 でCG 再現してしっぽを再生する。この作品をいつ も見ている人気番組「イメージボックス」(視聴者が 応募した CG 作品を放送する番組)へ送る(口絵写真 5).

この時代には，ユーザ側から放送局へ有線ネットワ ークを利用して容易にアクセスできるようになってい るとする. 放送局側もユーザからのいろいろな手段に よるアクセスを自動的に受け付けるシステムを備えて いよう. 放送局は, 放送した膨大な量の映像ソフトを 蓄積しており，オンデマンドでそれらをユーザに提供 するサービスを始めている可能性もある。これは, 見 逃した番組を見るニーズだけでなく, 学校の宿題のビ デオレポート作成に資料として利用するなど，いろい ろな利用方法が開けるであろう。

未来テレビの受信機は, スーパパソコンの内蔵によ り, 映像の加工や CG 制作機能も備え, 家庭でデスク トッププログラムプロダクションが可能になり, 個人 的楽しみ方のほか, 作品を紹介しあうチャンスなども 出現するであろう.

\section{・ パーティチャンネルに参加}

一あやかはふたたびリビングへ，未来のあやかは インタラクティブチャンネルの中からパーティチャ ンネルサービスにアクセスし, 自分がいま興味をも っている人工生命や新しい形式の番組を話題にして いるグループを選び参加する（口絵写真 6).
テレビは未知の人々が見ているメディアであり，見

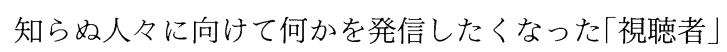
が「参加者」となることができるサービスである，放 送局は, ネットワークを利用し, いろいろなテーマの マルチメディア電子会議を主催し, 共有画面として の, マルチメディア「黒板」の画面を放送する。参加 者は，「黒板」に自らの意見・情報を書き込む。ただ し, 進行役は放送局にいてテーマや話題を提供し「お しゃべり」を盛り上げる。マルチメディア時代には， 放送局がこのような場を提供する可能性があろう.

\section{・ グローバル\&スーパーローカル放送の時代}

一あやかは，世界中の放送を見ることができる 「世界受信テレビ」や交通情報や関連ニュースを瞬時 に呼び出せ,テレビ電話にもなる「携帯総合端末」 などを体験し, クマに導かれ, ふたたび $199 \mathrm{X}$ 年 の世界に戻っていく.

マルチメディア時代では個人生活の国際化もますま す強まる．日本にいて海外の番組をもっと見たい，外 国にいて日本の番組を多く見たいというニーズに対 し, 光ファイバによる地球規模の多チャンネル国際放 送で応えていくことは充分可能であろう.

また, ハンディな携帯端末の中に映像機能が組み込 まれ，放送と通信機能が統合化されることは，コミュ ニティ放送にいつでもアクセスできるなど, 個人の生 活パターンにも影響を与える可能性をもつ。

\section{4. 未来テレビに何を求めるか?}

「Future Television 201X」では, 未来への夢もま じえ, 未来論的にマルチメディア時代のテレビ像を描 いたが,ここでは，もう一度受け手の観点から未来テ レビに何を求めるか考えてみる.

\section{1 生活・余暇行動のバーチャル化}

今後, 個人の生活・余暇時間における行動の中で電 子メディアへの接触を介在した行動（図 1 参照）の割 合が増加することはまちがいない。これは, 新聞, 雑 誌などの非電子メディアの電子化, 新たなネットワー クメディア利用行動の増加, さらには, 現在は実行動 型である行動の中からも電子メディアを介した行動に 変わっていくものが生じてくること, また, 基礎的行 動の中にも電子メディアを補助的に用いる行動が出現 する（例えば医療において）こと，などが考えられる からである。しかし, 電子メディアを介在したそれら の行動は, 個人生活の中に時間と距離を克服する効率 性をもたらす一方で, 行動のいっそうの仮想現実化 （バーチャル化）を促進する。もちろん, 人の情報選 択・受容の限界性から電子メディアへの接触行動は無 


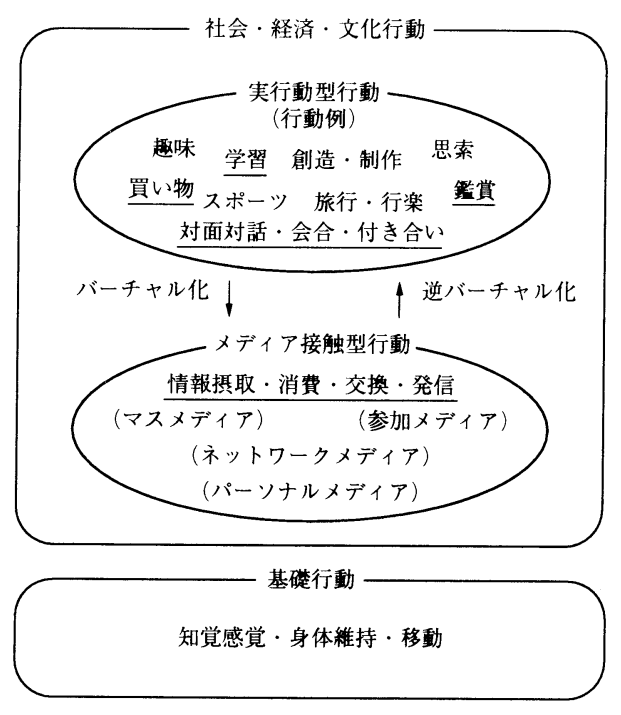

注）下線で電子メディアを介在するバーチャル化行動を示す．

図 1 生活・余暇行動のバーチャル化自己調節

制限に増加するのではなく（人を情報生命体としてと らえ，その限界性からテレビ視聴の選択・受容の「い いとこ取り行動」を論じた参考文献 6)参照)，また， 節約できた時間で実際にコンサートに出かけるなど， 実行動型へ戻る逆現象も生じ，個人はより充実した生 活を求め, メディア接触型と実行動型の分極化と最適 化の自己調節が生じよう.

このような電子メディアを介する「バーチャル化行 動」と実行動とのバランスは, 人間本来の健全性を維 持していくためにも必要であり, また, バーチャル化 行動そのものの質の吟味が重要になる. 最終的には, なによりも個人の生活のクォリティの向上につながる ものでなければならない. 電子メディアの中で, 今後 も個人が最も多く接すると考光られるテレビにも，バ 一チャル化行動の質をより高める方向での発展が求め られるはずである。

\section{2 未来テレビの提供するソフト空間}

テレビが提供している情報・ソフトの空間を個人の 視点から眺めると図 2 のように表せる。未来テレビに 求められるのは，（1）この空間を受け手のニーズをよ り満足させる形で「充填」，（2）この空間の拡大，およ び ( 3 ) 新次元の導入, と考えられる.

例えば( 2)では, 個人生活の近傍をうめるべく超口 ーカルに(コミュニティ放送はこの例になる)，同時に グローバルにも振り幅を大きく情報・ソフト空間を拡 大する。ニュースーエンタテイメント軸で見ると，情 報系表現と映像系表現力を拡大する。すなわち，テレ

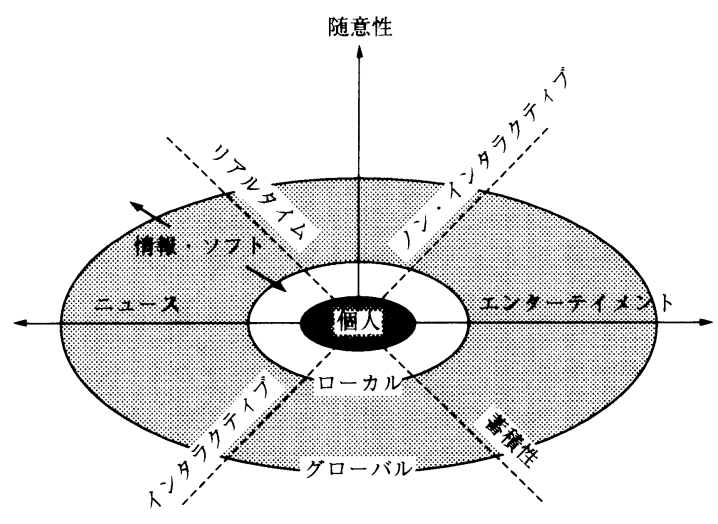

一マルチメディアによる情報・ソフト空間の拡大 -

図 2 個人から見た情報・ソフト空間のイメージ

ビのコンピュータ化により情報系ソフトはより集約 的，簡潔に(理解しやすい形で)そしてクリッキング可 能（画面をクリックすることにより画面の内容が変化 すること）にする．また，映像系ソフトは，超高精細 立体映像などの導入で, より高品質, 透明に（表現上 の妨げが少ない状態をいうことにする)する。そして， リアルタイム性の拡大と同時に蓄積性を拡大する。

（3）では，これまでの放送情報・ソフトにはない新 次元として「インタラクティブ (対話性, 双方向性) 軸」と, 個人の生活パターン優先につながる「随意性 (いつでも，オンデマンド)軸」を導入する。これらは， 放送のマルチメディア化による機能的拡大である.

テレビはこれまで, 電子映像文化を切り開くパイオ ニアとしての役割を果たしてきたが，（2）の放送情 報・ソフト空間の拡大における映像表現力の拡大は, その伝統的延長線上にあるといえる。

遠くのものを見たいという欲求がテレビジョンの発 明に結び付いたといわれる。しかし，遠くのものを見 せられることはあっても, 遠くのものをみることはで きないのが今日のテレビではなかろうか？

スポーツ中継やコンサート中継でも，実際に競技場 や会場に行って観戦, 鑑賞するのと違って, いろいろ なカメラアングルが切り替えられ, 映像効果や解説や 効果音が加えられる. それは, 野球場やコンサート会 場にあたかも行ったようにして見られるのではない． なぜ, 野球場の一番良い席に全体を映し出せるレンズ をつけたテレビカメラを据え, そのまま放送するので はないのだろうか？ 色濃く演出しない透明度の高い 映像では, 受け手がより主体的になれ, バーチャル化 行動の質を高め得るといえるのではないか．このよう な仮説が成り立つとすると, 未来テレビには, マルチ 
メディアによる機能的な拡大とともに，これまでテレ ビが発展してきた方向をさらに発展させ, いっそう映 像表現力を拡大することが求められる.

\section{5.む す び}

生活者個人の属性は, 幼児, 若者から高齢者, 児 童・学生から主婦・職業人, 健康か病気か, ハンディ キャップ, 都会に住む, 地方に住む, など非常に多様 である、テレビはこのように多様な，すべての受け手 を対象にする基本メディアとして発展してきた．末来 テレビを含む電子メディアのマルチメディア軸上の今 後の発展が, 個人の生活に大きな影響を与えることは 間違いないが，それが個人の生活の質を向上させるも のであり，「ひと」として健全に生きることに役立つ手 段とすることができるかどうかは今後にかかってい る。

それには，技術的可能性や経済性の追及だけでな く,ソフト, サービスのあり方を, 多様である生活者 個人の視点から，また，メディアとひとのより本質的 なかかわりから検討していく必要があろう.
本論をまとめるにあたり, 長屋龍人氏（NHK 放送 文化研究所）にご議論をいただいた。

(1995 年 7 月 12 日受付)

\section{〔参 考 文 献〕}

1）堤, 本田：“視聴者意識に新しいきざし”, 放送研究と調査, 6 , pp. 2-13, 58-59 (1988)

2）松澤, 白石, 中野：“日本人とテレビ・1995”, 放送研究と調査, 7, pp. 2-13 (1995)

3）謝名元，佐藤：“テレビ・ラジオ視聴の現況”，放送研究と調 查, 9, pp. 24-35 (1994)

4）白石：“団塊ジュニアのメディア感覚”, 放送研究と調查，4, pp. 22-27 (1994)

5）柳町：“ISDB による放送サービスの高度化とマルチメディ ア”, NHK 技研 R \& D, 33, pp. 3-12（Sep. 1994）

6）長屋: “情報と脳の器一人間の情報処理限界性といいとこ取 り行動の基碟原理”，NHK 放送文化研究年報, 40（1995）

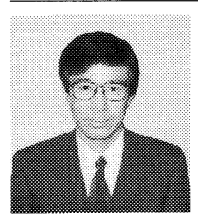

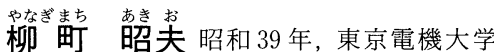
卒業. 昭和 34 年, NHK 亿入局. 以来, 同 放送技術研究所俋て, 文字放送, 静止画放 送, 衛星デー夕放送およびISDB の研究, 開 発に従事. 現在, 同所研究主幹（特別プロジ エクトマルチメディアラボ担当)，正会員．

\section{2-5 マルチメディア時代の放送サービス \\ 一技術的可能性と視聴者選択一}

\section{1. まえ がき}

マルチメディア時代の放送といえば，すぐにあげら れるのが, 多メディア化・多チャンネル化, 双方向 化・インタラクティブ化といった, 技術的機能・特性 による分類や将来展望である。これらの展望を聞く と, わかったような気分になるかもしれないが, 実際 の実務者からすれば，肝心のことがわからない。それ は, マルチメディア時代の実際の新サービスがいかな る型になるかは, これらの技術的機能・特性が,

\section{$\dagger$ NHK 放送文化研究所}

" $2-5$ New Broadcasting Services in Multimedia Age; Their Technological Possibilities and Audience's Choice" by Tatsuhito Nagaya (NHK Broadcasting Culture Research Institute, Tokyo)

\section{長 屋 龍 ${ }^{\dagger}$}

(1) どのメディア(伝送手段)で実現され

(2) どのような家庭端末で可能となり

(3) 事業主体がだれか

(4) コストはどれくらいか

などが確定しなくては，

(5) 具体的なソフトと

(6) サービス形態の将来像

は見えてこないのである。

放送は〈ソフト制作一伝送・表示手段一視聴者選択〉 の総体で成り立っており，視聴者がく限りある “時間” と“金銭”と“関心”をいかに注いでくれるか〉が, 最 後にサービスの量と質と型を決定するのである.

問題は，個々の技術的革新よりも，“全体として人 間のニーズ”に合い，適度な“值頃感”内に納まり，人 間に優しい“柔軟なメディア”であるか否かである。 